\title{
Käytännön kokemuksesta oppiminen teknologisten muutosten lähteenä
}

\begin{abstract}
Lovio, Raimo 1987. Käytännön kokemuksesta oppiminen teknologisten muutosten lähteenä. Aikuiskasvatus 7, 4. 145-150. - Tässä kirjoituksessa pyritään osoittamaan Suomen elektroniikkateollisuuden innovaatioita koskevan tutkimuksen ja taloustieteellisen teknologisia muutoksia koskevan kirjallisuuden avulla, kuinka huomattava merkitys käytännön kokemuksesta oppimisella on teknologisten järjestelmien toiminnassa ja kehittämisessä.
\end{abstract}

Taloustieteellisessä tutkimuksessa on 1950luvun loppupuolelta lähtien analysoitu empiirisesti innovaatioiden syntyyn ja teknologiseen kehitykseen vaikuttavia tekijöitä. 1980-luvulle tultaessa tutkimuksessa varsin yleisesti päädyttiin kolmen selitystekijän malliin. Nämä selitystekijät ovat:

-- tieteellis-teknisen tutkimuksen tarjoamat uudet mahdollisuudet (science push)

- uudet yhteiskunnalliset tarpeet, jotka enemmän tai vähemmän selvästi välittyvät markkinoilla maksukykyisenä kysyntänä (market pull)

- tekniikan tuottajien ja käyttäjien käytännön toiminnassa kertyvä kokemus ja sen pohjalta tapahtuva oppiminen (learning by experience).

Olennaista nykyisessä käsityksessä on se, että näitä selitystekijöitä ei nähdä toisiaan poissulkevina tai kilpailevina tekijöinä, vaan tekijöinä, jotka vaikuttavat nimenomaisesti yhdessä innovaatioiden syntyyn. Innovaatiot näyttävät syntyvän juuri silloin, kun tieteen tarjoamat uudet mahdollisuudet (potentiaalisesti hyvät vastaukset) kohtaavat uudet polttavat yhteiskunnalliset tarpeet (hyvät kysymykset) sellaisessa yhteydessä, jossa uusien ratkaisujen etsimisessä voidaan nojata käytännössä kertyneeseen kokemukseen (ks. esim. Lemola/Lovio 1984, 15-32 ja Miettinen 1987 ja niissä viitattu kirjallisuus).

Seuraavassa rajaudun kuitenkin tarkastelemaan vain käytännön kokemuksesta oppimi- seen liittyviä näkökohtia, koska se saattaa olla mielenkiintoista muunkin oppimistoimintaa koskevan tutkimuksen kannalta. Varoitukseksi lukijalle on tosin heti sanottava, etteivät taloustieteilijöiden käsitemäärittelyt tällä alueella ole kovin hienosyisiä ja systemaattisesta teoriasta johdettuja. Pikemminkin ne ovat yleistyksiä ja nimityksiä empiirisessä tutkimuksessa havaituille ilmiöille. Taloustieteilijöiden tutkimukset auttanevat kuitenkin ehkä ymmärtämään joitakin ei-yksilötasoisten oppimisprosessien piirteitä.

\section{Esimerkkejä}

Lähden liikkeelle esimerkkitapauksista, joihin olen perehtynyt tutkiessani yhdessä Tarmo Lemolan kanssa Suomen elektroniikkateollisuuden merkittäviä innovaatioita (tutkitut 21 tapausta on raportoitu tarkemmin julkaisussa Lovio 1987).

Esimerkki 1.

Uuden tuotantoteknologian luomisen vaikeus.

Eräs tutkimistamme innovaatioista on Lohja Oy:n elektroluminenssinäyttötekniikka. Hanketta on vuodesta 1977 lähtien toteutettu Lohja Oy:ssä, mutta se käynnistyi vuonna 1974 Instrumentarium Oy:n Datex-yksikössä. Yritys palkkasi tuolloin TkT Tuomo Suntolan kehittämään yhtiölle uusia tuotteita. Suntola oli aiemmin tehnyt väitöskirjan amorfisista ohutkalvoista ja ollut kehittämässä ohutkalvotekniikkaan perustuvan kosteusanturin Vaisala Oy:Ile. Tältä perustalta syntyi ajatus, että elektroluminenssi-ilmiö (joka on ollut tunnettu vuodesta 1936) voitaisiin saada aikaisempaa 
parempaan hallintaan uudenlaisella ohutkalvojen valmistusmenetelmällä. Tällöin olisi mahdollista valmistaa elektroluminenssiin perustuvia litteitä näyttöjä, joilla puolestaan näytti olevan lupaavat markkinat (kannettavat mikrot, taulutelevisiot jne.). Idea ALE-menetelmästä (atomikerroksittain tapahtuva yhdistepuolijohdeohutkalvojen valmistusmenetelmä) syntyi loppukeväällä 1974 ja se voitiin demonstroida alkeellisin laboratoriojärjestelyin saman vuoden syksyllä. Ensimmäinen patenttihakemus jätettiin marraskuussa.

Todelliset vaikeudet olivat kuitenkin vasta edessäpäin. Tutkimusryhmä ryhtyi kehittämään laitetekniikkaa, jolla ALE-menetelmä voitiin toteuttaa. Kolmen vuoden työn jälkeen tutkimusryhmä joutui toteamaan, että kehitetty laitekanta johti umpikujaan, minkä vuoksi suuntauduttiin uudentyyppisen laitekannan kehittämiseen. Nyt valittu suunta oli oikea ja ensimmäiset laboratorioprototyypit valmistettiin vuonna 1979. Seuraavana vuonna tehtiin päätös koetuotantolaitoksen rakentamisesta.

Koetuotantolaitoksen valmistuminen toi esiin uusia ongelmia: teolliseen mittakaavaan siirtyminen edellytti edelleen uusien teknisten ratkaisujen kehittämistä. Pian jouduttiinkin toteamaan, että prosessin hallintaan saattamiseksi on välttämätöntä rakentaa kokonaan uusi tehdas. Tehdas valmistui vuonna 1986, mutta prosessin hallinnassa on edelleen vaikeuksia.

Tekniseen perustutkimukseen pohjautuvan ALE-menetelmän teollinen käyttöönotto kesti siis 12 vuotta.

\section{Esimerkki 2. \\ Teknologian siirron onnistumisen edelly- tykset.}

Nokia Oy, Aspo Oy ja Salora Oy perustivat vuonna 1980 Micronas Oy:n suunnittelemaan ja valmistamaan Suomen elektroniikkateollisuudelle ns. sovellutuskohtaisia integroituja piirejä (ASIC). Koska Suomessa ei ollut alan teollista osaamista, yrityksen teknologia päätettiin ostaa lisenssisopimuksella ulkomailta. Yhteistyökumppaniksi valittiin kalifornialainen Micro Power Systems Inc.

Tehty lisenssisopimus muotoiltiin poikkeuksellisesti teknologian "noutosopimukseksi". Sopimuksen nojalla yhtiö koulutti 10 henkilöä vuoden pituisina jaksoina Kaliforniassa. Tuona aikana koulutettavat suunnittelivat piirejä suomalaisten käyttöön sekä perehtyivät valmistustekniikkaan. Suunniteltujen piirien valmistus aloitettiin Kaliforniassa, josta se vuonna 1986 siirrettiin Espooseen valmistuneeseen uuteen tehtaaseen.
Teknologian siirto onnistui hyvin. Miksi? Yrityksen edustajien mukaan nimenomaan siksi, että teknologia noudettiin. Siirtoprojektiin osallistuneet henkilöt valittiin huolellisesti. Hyvän peruskoulutuksen saaneet suomalaiset insinöörit kävivät paikan päällä läpi prosessin jokaisen vaiheen ja kysyivät alituisesti: miksi tämä tehdään näin? Näin he pystyivät selvittämään valmistuksessa noudatettavien sääntöjen perusteita ja myös löytämään lopputulokseen olennaisesti vaikuttavia yksityiskohtia, joita ei ollut mihinkään dokumentoitu. Uuden tehtaan suunnittelussa ja rakentamisessa voitiin myös nojata VTT:n ja Vaisala Oy:n pienimuotoisten integroitujen piirien valmistuslinjoista saatuihin kokemuksiin sekä Suomessa 1980-luvulla eräissä muissa tehdasprojekteissa kertyneeseen puhdastilarakentamisen osaamiseen.

\section{Esimerkki 3. \\ Uuteen tuotantoon diversifioitumisen vai- keus.}

Vanha metsäteollisuusyritys Kajaani Oy päätti vuonna 1969 lähteä kehittämään elektroniikkatuotantoa saadakseen uuden kasvualan perinteisten alojen rinnalle. Perustettu yksikkö valmisti aluksi selluteollisuuden automatisoinnissa tarvittavia mittalaitteita, mutta vähitellen tuotevalikoima laajeni varsin laajaksi. Yksikön toiminta oli kannattamatonta ja siksi Kajaani Oy lopulta vuonna 1983 päätti myydä yrityksen Valmet Oy:lle, jonka suojissa yrityksestä on kolmeksi yritykseksi hajautettuna muodostunut kannattavaa liiketoimintaa.

Miksi Kajaani epäonnistui? Erään selityksen tarjoaa yhtiön historiasta kertova tuore kirja: "Elektroniikan nopearytmisen tuotannon ja markkinoinnin kannalta olivat laitostumiseen taipuvan metsäteollisuusyrityksen sisäiset järjestelmät liian jähmeät. Voimavarojen suuntaaminen ajankohtaisiin hankkeisiin oli vaikeaa. Elektroniikkayksikkö ei toisaalta osannut sopeutua keskushallinnon vaatimuksiin, ja toisaalta keskushallinto ei aina tiennyt, mitkä narut oli pidettävä tiukalla, mitkä löysällä. ...Osa yhtiön johtokunnasta oli jo elektroniikkateollisuuden aloittamista pohdittaessa ounastellut, ettei uusi ala sopeutuisi hyvin metsäteollisuusyrityksen osaksi. He ehdottivat erillisen yrityksen perustamista. Vähitellen yhtiön johto kypsyikin siihen." (Virtanen 1985, 95-96)

Kajaani Oy:n metsäteollisuudesta juontuvat toimintamallit olivat siis sopimattomia elektroniikkateollisuudessa. Sen omalla kokemuksella ei ollut käyttöä uuden tuotannon kehittämisessä. 
Tutkimusaineistomme mukaan Suomen elektroniikkateollisuuden innovaatioista ovatkin pääasiassa vastanneet vanhat sähkötekniikan, koneiden ja instrumenttien valmistajat. Menestys on usein perustunut siihen, että yrityksen vanha tuote on uudistettu mikroelektroniikan tarjoamilla uusilla mahdollisuuksilla (esimerkiksi Salora Oy:n väritelevisiot, Kone Oy:n hissit, Telenokia Oy:n puhelinkeskukset, Vaisala Oy:n radiosondit, Valmet Oy:n automaatiojärjestelmät) tai siihen että uusi tuote oli tarkoituksellisesti kehitetty yrityksen vanhalle liiketoiminta-alueelle (esimerkiksi Teleste Oy:n kaapeli-tv-laitteet, Instrumentarium Oy:n magneettikuvauslaite).

\section{Esimerkkien alustava tulkinta}

Edellä lyhyesti kuvatut esimerkit voidaan tulkita valottavan learning by experience -lähestymistavassa korostettavia seikkoja (ks. tarkemmin esim. Sahal 1981, Pavitt 1984).

Elektroluminenssitekniikkaa koskeva esimerkki valottaa mielestäni hyvin sitä tässä lähestymistavassa korostettavaa seikkaa, että teknologia eroaa olennaisella tavalla tieteestä, vaikkakin teknologia on kasvavassa määrin vuorovaikutussuhteessa tieteen kanssa. Toimivat teknologiset järjestelmät pohjautuvat teorian lisäksi empiirisiin havaintoihin, jotka on löydetty käytännössä yrityksen ja erehdyksen tai systemaattisten kokeilujen kautta. Teknologia on sananmukaisesti taitotietoa (tekhne $=$ taito, $\log o s=$ tieto) tai tietotaitoa (knowhow).

Koska teknologia ei ole puhdasta teoriaa, sitä ei voida luonnehtia julkiseksi informaatioksi, jota voi kuka tahansa ilman vaivaa ja kustannuksia soveltaa. Micronas Oy:n esimerkki kuvaa hyvin, kuinka vaikeaa teknologian siirtäminen yrityksestä ja maasta toiseen on juuri tämän takia. Toimivaąn teknologiseen järjestelmään sisältyy aina kokemukseen pohjautuvia toimintamalleja ja sääntöjä. Koska kaikkia niitä ei dokumentoida tai kunnolla edes tiedosteta, osa teknologiasta on tavallaan "näkymätöntä". Tähän näkymättömään osaan törmätään vasta käytännön ongelmatilanteissa.

Ja juuri siksi vähittäin kumuloituvalla käytännöllisellä kokemuksella on suuri merkitys teknologian kehityksessä. Uutta teknologiaa ei synny tyhjästä, jostakin kokonaan uudesta, vaan suurelta osin vanhan tekniikan tuottamisessa ja käyttämisessä syntyvän kokemuksen, oppimisen ja ongelmatilanteiden ratkaisemisen kautta. Kajaani Oy:n tapaus on tästä negatiivinen esimerkki, vaikkakin lähinnä liikkeenjohdollisten toimintamallien tasolla.

\section{Täsmennyksiä}

Taloustieteellisessä teknologiatutkimuksessa edellä esitettyjä näkökohtia korosti eräänä ensimmäisistä yhdysvaltalainen taloustieteilijä Kenneth Arrow. Hänen artikkelinsa The Economic Implications of Learning by Doing vuodelta 1962 loi perustan, jolta näkemystä on sittemmin kehitetty.

Arrowin artikkeli liittyi tuolloin vilkkaana käytyyn keskusteluun siitä, miten makrotaloudellisissa tuotantofunktioissa ilmenevä tekninen muutos (tuottavuuden kasvu) voitaisiin mallittaa. Arrowin ratkaisu ongelmaan oli tavanomainen: teknologisia muutoksia selittäväksi muuttujaksi hän valitsi bruttoinvestoinnit (koska uusi tekniikka välittyy tuotantoon niiden kautta). Arrow ei kuitenkaan tyytynyt tähän tavanomaiseen ratkaisuun, vaan pyrki myös osoittamaan, mistä uudet tekniset ratkaisut syntyvät esittämällä ns. learning by doing -hypoteesin.

Arrow lähti siitä, että tekniset uudistukset ovat oppimisprosessin tulosta ja että oppimista voi tapahtua vain yritettäessä ratkaista ongelmia ja siksi oppiminen tapahtuu todellisen toiminnan yhteydessä. Tästä seuraa hänen mukaansa, että olennainen osa teknillistä kehitystä ei ole yrityksen kannalta ulkopuolista, markkinoilta ostettavaa tietoa, vaan se syntyy yrityksen sisällä siitä kokemuksesta, joka on peräisin sen oman tuotantoprosessin kehittämisestä. Mitä pidempään yritys on harjoittanut toimintaa alalla ja mitä laajempaa sen tuotanto on, sen nopeammin kokemusta kumuloituu. Kokemuksen pohjalta syntyy parannusinnovaatioita, jotka voidaan ottaa käyttöön yrityksen seuraavan periodin kone- ja laiteinvestoinneissa.

Arrowin hypoteesia on sittemmin täsmennetty monessa suhteessa. Mainitsen niistä tässä vain tärkeimmät.

1. Ensinnäkin on haluttu tehdä ero sen välille, milloin kertyvä kokemus johtaa vain parempaan olemassaolevan tekniikan käyttöön ja milloin se todella johtaa uusiin innovaatioihin. Klassinen tutkimus käytännön kokemuksesta oppimisen merkityksestä olemassaolevan tekniikan käytön parantumisessa on ruotsalaisen Erik Lundbergin (1961) Horndalin terästehdasta koskeva tutkimus. Lundberg osoitti tutkimuksessaan, että vaikka tehtaan teknologiassa ei tehty 15 vuoden aikana mitään olennaisia investointeja vaatineita muutoksia, niin silti tehtaan tuotos tehtyä työtuntia kohti kasvoi keskimäärin $2 \%$ vuodessa samana aikana. Sama ilmiö on tuttu jokaiselle tehdasta "ylösajaneelle" insinöörille: maksimi- 
tuottoihin päästään harvoin alkuvaiheessa. Myös jokainen mikron käyttäjä tuntee ilmiön: alkuvaiheessa liuskan virheetöntä tekstiä pystyy tuottamaan paperille halutussa muodossa noin päivän työn jälkeen, myöhemmin samaan kuluu aikaa enää alle puoli tuntia.

Tästä eteenpäin pääseminen edellyttääkin sitten usein uusia ratkaisuja, mutta syntyneellä kokemuksella on merkitystä tässäkin suhteessa. Esimerkiksi mikron käyttäjä oppii kokemuksensa kautta, että hänen työskentelynsä olisi nopeampaa, jos ohjelmistoa voitaisiin parantaa siten, että ..., jos näytössä näkyisi se ja se, jos näppäimistön rakennetta muutettaisiin siten, että ... jne.

2. Tästä päästäänkin luontevasti toiseen täsmennykseen. Arrow antoi hypoteesilleen alunperin nimen learning by doing, koska hänen näkökulmansa oli teollisuuden tuottavuuskehityksen selittäminen. Nathan Rosenberg (1982, 120-140) on tuonut tämän käsitteen rinnalle termin learning by using, joka onkin varsin olennainen täsmennys jos "doing" ymmärretään suppeasti vain tuotteen valmistamiseksi. Rosenbergin esimerkki oli lentokonetekniikan kehitys, jossa lentoyhtiöillä ja lentäjillä, siis tekniikan käyttäjillä on ollut olennainen merkitys.

Omassa tutkimusaineistossamme oli myös muutama hyvä esimerkki siitä, kuinka tekniikan käyttäjän kohtaamat ongelmat saattavat johtaa innovaatioihin. Esimerkiksi kalibraattoreita valmistavan Beamex Oy:n syntyhistoria osoittautui seuraavaksi: Yrityksen perustajat toimivat 1970-luvulla Schaumanin paperi- ja selluteollisuuden instrumenttiosastolla ja keskuskorjaamossa Pietarsaaressa. Täällä he käytännössä törmäsivät tilanteeseen, että prosessiautomaation huoltopuolella ei ollut kunnollisia heidän tarvitsemiaan laitteita ja mittareita. Ulkomaalaisten erilaisten laitteiden testaamisen myötä he vähitellen vakuuttuivat siitä, että he pystyisivät tekemään parempia, tarkemmin käyttäjän tarpeita palvelevia kalibraattoreita. Näitä kehittämään ja valmistamaan perustettiinkin sitten yritys.

Vastaavanlainen esimerkki käyttäjän havaitsemasta puutteesta syntyvästä innovaatiosta on aineistossamme Labsystems Oy:n säädettävät monikanavaiset nesteannostelijat (pipetit). Lääket.lis. Osmo Suovaniemi sai idean tähän tuotteeseen "vääntäessään kokeita yökausia" lääketieteellisen kemian laitoksella ja havaitessaan kuinka alkeellisia silloiset pipetit olivat. Suovaniemi kehitti pipettiin uuden säätötavan, niputti yhdeksän koeputkea yhteen (jolloin näytteitä voitiin ottaa yhdeksän kerrallaan) ja otti käyttöön aikaisemman horisontaalisen fotometrian tilalle vertikaalisen foto- metrian, jollon rinnakkaisia koeputkia saatettiin mitata ylhäältä päin yhtäaikaa.

Useat innovaatiotutkijat korostavatkin nykyisin tuottajien ja käyttäjien keskinäisen yhteistyön merkitystä uusien ratkaisujen löytämisessä (esim. Lundvall 1985). Tuottajan erityisenä näkökulmana ja tavoitteena on kehittää tuotetta siten, että se on mahdollisimman helposti ja halvalla tuotettavissa, kun taas käyttäjän tavoitteena on saada siihen juuri hänen tarvitsemansa toiminnalliset ominaisuudet.

Tekniikan tuottajat ja käyttäjät muodostavat eräänlaisen kansantalouden kehitysverkoston, johon kuuluvat sekä toimialojen sisäiset tuotantoketjut että toimialojen väliset kytkennät. Suomen teollisuushistoriassa tärkein kehitysverkosto on kulkenut metsätaloudesta metsäteollisuuteen, sieltä koneteollisuuteen ja edelleen elektroniikkateollisuuteen ja suunnittelutoimintaan. Se että Valmet Oy on tällä hetkellä maailman suurin paperikoneiden ja metsäteollisuuden automaatiojärjestelmien valmistaja ja että Jaakko Pöyry Oy on eräs suurimmista alan insinööritoimistoista maailmassa, on ymmärrettävissä vain erittäin pitkäaikaisen teknologisen tietotaidon kumuloitumisen tuloksena.

3. Edelleen tutkimuksessa on pyritty täsmentämään teollisessa käytännössä syntyviä oppimistilanteita. Useimmiten nämä tilanteet ilmenevät erilaisina pullonkaulatyyppisinä tilanteina, jotka ovat seurausta tuotanto- tai käyttötoimintojen kehittymisestä tai vanhan tekniikan soveltamisesta uusiin olosuhteisiin. Tällöin törmätään tilanteisiin, jossa käytettävällä tekniikalla on ei-toivottavia tai kokonaan puuttuvia ominaisuuksia.

Devendra Sahal (1981) on korostanut, että monet käytännön oppimistilanteet teollisuudessa syntyvät skaalamuutoksista. Kun samaa tuotetta valmistetaan aikaisemman sadan sijasta tuhat samana päivänä, syntyy tuotantoprosessiin jatkuvasti uudentyyppisiä pullonkaulatilanteita, joiden ratkaiseminen saattaa johtaa merkittäviinkin innovaatioihin. Vastaavasti itse tuotteen skaalan (esim. koon tai maksimitehon) muuttamisessa törmätään ongelmiin, jotka edellyttävät uudenlaisia ratkaisuja tuotteen rakenteessa ja tekniikassa.

4. Käytännön kokemuksesta oppımısen merkitys ei ole tietysti yhtä tärkeää kaikilla tuotannon aloilla eikä kaikissa teknisen kehityksen vaiheissa. Mutta kuten esimerkkimme osoittavat, jopa elektroniikkateollisuudessa, jossa tutkimustoiminnalla on varsin keskeinen rooli, käytännön kokemuksen merkitys saattaa olla huomattava. Sen merkitys on yleensä vä- 
häisempi todella radikaaleissa, perustavanlaatuisissa innovaatioissa, mutta suuri näiden ini: uviaatioiden vähittäisessä kehittämisessä kohit potentiaalista rajaansa.

\section{Mihin kùytännöllisestä kokemuksesta oppimisen merkitys perustuu?}

Edellä on nyt hahmotettu stä tapaa, jolla taloustieteilijät ovat yrittäneoł lasentää käytännöllisen kokemuksen ja (1)mm men mitystä tekniikan kehityksessä. Vielä on kuitenkin oikeastaan vastaamatta kysymys, mihin tämä kiistattomalta näyttävä merkitys viime kädessä perustuu. Vastaaminen tähän kysymykseen nävtlda palautuvan kysymykseen teknisten järjestelmen luonteesta.

Ensimmäinen perustelu näyttäisi olevan se, että tekniset järjestelmät ovat aina luonteeltaan hyvin spesifejä ja kompleksisia. Kun tiede pyrkii etsimään yleisiä lainalaisuuksia ja näin tehdessään pyrkii vakioimaan tutkittavat olosuhteet, niin tekniset järjestelmät tuottavat mitä erilaisimpia tuotteita mitä erilaisimmissa olosuhteissa. Tämä merkitsee sitä, että monia ratkaisuja ei voida helposti ja vaivattomasti johtaa yleisestä teoriasta, vaan on käytännön kautta haettava kussakin konkreettisessa tilanteessa parhaita mahdollisia ratkaisuja. Matka "todesta teoriasta" "toimivaksi järjestelmäksi" on pitkä. Tätä osoittaa myös se, että yritysten harjoittamasta tutkimus- ja kehittämistoiminnasta yleensä 3,4 on kehittämistoimintaa ja että uuden tuotannon käyntiin saattamiskustannukset yleensä ylittävät tutkimus- ja kehitystoiminnan menot (Pavitt 1984, 348).

Ja toiseksi: usein teknisiä järjestelmiä kehitetään jo ennen kuin on edes olemassa järjestelmän toimintaa selittävää teoriaa, tekniikka usein edeltää ja itse asiassa suuntaa tieteellistä tutkimusta (ks. esim. Rosenberg 1982, 141-159, Price 1984). Ajankohtainen esimerkki tästä on suprajohtavuus-ilmiö. Tämä ilmiö keksittiin 1911. Ilmiön metalliseoksissa selittävä teoria kehitettiin 1957, mutta viime aikoina kehitetyt uudet keraamiset suprajohteet ovat osoittaneet, että teoriassa on puutteita. Täsmällinen teorian puuttuminen ei ole kuitenkaan estänyt insinöörejä etsimästä kokeilemalla uusia entistä lämpimämmissä olosuhteissa toimivia suprajohteita ja kehittämästä ilmiön hyödyntämiseen liittyviä teknisiä sovellutuksia. Esimerkiksi Outokumpu Oy on jo koettanut valmistaa näihin uusiin keraamisiin yhdisteisiin perustuvia sähköjohtoja ja valmistaa metalliseoksiin perustuvaa suprajohdekaapelia kaupallisestikin. Teknisiä järjestelmiä ke- hittäville ihmısille ja niitä myyville yrityksille tärkeintä on. extä järjestelmät toimivat. Ennemmin tai mvöhemmin teoreettinen tutkimus pystyy usoittanaan, mihin toiminta perustuu, ja se avaa usenn uusia mahdollisuuksia järjestelmän kehittämiseen.

Kolmas ja ilmeisesti varsin tärkeä selitys kokemuksesta oppimisen merkitykselle on se, että tekniset järjestelmät ovat itse asiassa aina sosio-teknisiä järjestelmiä: ihmisten käyttämiä järjestelmiä luonnon manipuloimiseksi täsmälleen haluttuun tarkoitukseen erityisissä olosuhteissa. Esimerkiksi suurissa tehtaissa vain osalla käyttöhenkilökunnasta on sellainen koulutus, jonka avulla on todella mahdollista ymmärtää käytettävän järjestelmän toiminnan perusteet. Suuri osa toimii "ulkoaopittujen" sääntöjen ja käytännön kokemukseen perustuvien taitojen perusteella.

\section{Johtopäätökset}

Edellä esitetystä, ehkä jopa hieman liikaa käytännön kokemuksesta oppimisen merkitystä korostavasta tarkastelusta voidaan tehdä ainakin kaksi johtopäätöstä.

Ensimmäinen koskee teknologiapolitiikkaa. Vaikuttaa kaikin puolin perustellulta yleensä noudattaa politiikkaa, jossa uusia teknologisia ratkaisuja lähdetään etsimään vanhan osaamisen ja uusien mahdollisuuksien leikkausalueilta. Pienessä maassa tämä merkitsee usein uuden kansainvälisen tieteellis-teknisen tutkimuksen ja kansallisen teknologisen tradition hedelmällisimpien leikkauspisteiden hakemista ja kehittämistä.

Toinen johtopäätös koskee erilaisten tuotantoprosessien kehittämiseen tähtääviä kehittämishankkeita. Ensimmäinen vaihe näissä hankkeissa tulisi olla prosesseihin ja niiden käyttöön sisältyvän "näkymättömän" tietotaidon esilletuominen. Tämän jälkeen tämä käytännöllinen tieto voidaan systematisoida ja arvioida, jolloin voidaan ehkä osoittaa kriittisiä kysymyksiä, joihin tulisi lähteä etsimään täsmällisemipään tietoon ja teoriaan perustuvia ratkaisuja.

\section{Lähteet}

Arrow, K. 1962. The economic implications of learning by doing. Review of Economic Studies 29, $155-173$.

Lemola, T. \& Lovio, R. 1984. Näkökulmia teollisuuden innovaatiotoimintaan ja teknologiapolitiikkaan Suomessa 1980-luvulla. Helsinki: Valtioneuvoston kanslian julkaisuja 1984:2. 
Lovio, R. 1987. Suomen elektroniikkateollisuuden innovaatiotoiminnan ongelmat ja menestystekijät. STIU-projektin työpapereita 4. Espoo: Valtion teknillinen tutkimuskeskus, Suunnittelu- ja markkinointitoimisto.

Lundberg, E. 1961. Produktivitet och räntabilitet. Stockholm: Norstedt and Söner.

Lundvall, B-Å. 1985. Product innovation and userproducer interaction. Aalborg: Aalborg University Press.

Miettinen, R. 1987. Tiedeyhteisö, teknologiayhteisö, työyhteisö: missä yhteisöissä tiedettä tehdään? Julkaisussa Lehti, R. ja Häyry, M. (toim.): Tiedeyhteisö - onko sitä? Suomen Akatemian julkaisuja 4/1987. S. 81-114.
Pavitt, K. 1984. Sectoral patterns of technical change: towards a taxonomy and a theory. Research Policy 13, 343-373.

Price, D. 1984. Of sealing wax and string. Natural History 1, 49-56.

Rosenberg, N. 1982. Inside the black box: technology and economics. Cambridge: Cambridge University Press.

Sahal, D. 1981. Patterns of technological innovation. Massachusetts: Addison-Wesley.

Virtanen, S. 1985. Puusta elävä: Kajaani Oy:n vaiheita vuodesta 1946. Helsinki: Kajaani Oy. 


\section{AIKUISKASVATUS}

\section{The Finnish Journal of Adult Education \\ Vol. 7, 4/1987 \\ ISSN 0358-6197}

Summary

Lovio, Raimo 1987. Learning from Practical Experience as a Source of Technological Change.

By making use of research carried out in Finland on innovations in the electronics industry and economic studies dealing with technological changes, the author aims to show the significance that learning from practical experience has in the functioning of technological systems and in developing them. 